\title{
A RACE-HORSE CALLED PHERENIKOS
}

\author{
W J Henderson (University of Johannesburg)
}

The aptly-named stallion Pherenikos (Victory-bearer) raced and won for Hieron, tyrant of Gela (485 BC) and Syracuse (485-467/6 BC). This is the only horse that is named in the surviving victory odes (epinikia) of Pindar and Bacchylides. ${ }^{1} \mathrm{He}$

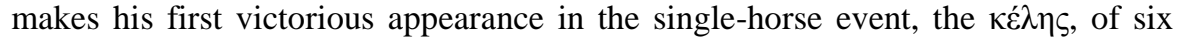
laps (just over $1 \mathrm{~km}$ ) in the hippodrome at the Pythia in 478, to which Pindar refers in $P$. 3.72-74, composed sometime after $476 .^{2}$ This is probably the victory to which Bacchylides (5.41) refers when he states that Pherenikos won at Delphi before his victory at Olympia in $476 .^{3}$

\author{
$\ldots \mu \varepsilon \grave{v} \delta \delta \delta v ́ \mu \alpha \varsigma \chi \alpha \dot{\rho} \rho \tau \alpha \varsigma$

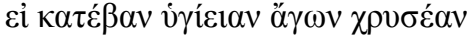

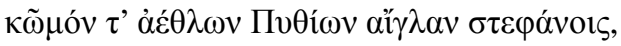

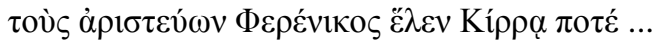 \\ $\ldots$ and if I had come down, \\ bringing double blessings, golden health \\ and celebration as lustre for the crowns of the Pythian Games, \\ which victorious Pherenikos carried off at Kirrha once ...
}

Nothing is said about the horse apart from his earlier victory, but scholars have debated issues raised by this event. Jebb, following the scholiast, ${ }^{4}$ argued that the

$1 \quad$ Bernardini 1985:126. Pind. P. 10.16 mentions a Phrikias, which could be the name of the winner's horse or his father. It is more likely the father, who would certainly be known to family, friends and fans, and be readily identifiable, whereas the horse would not and would therefore require some explanation in the text of the ode. Plutarch (6.13.9) tells of a mare, Aura, owned by Pheidolas, that won at Olympia in 512, despite having lost her jockey at the start; cf. Hemingway 2004:118-119; Miller 2004:57 no. 71; 2004b:79.

2 The ode, primarily concerned with Hieron's ill-health, was 'probably classed among the epinikia by the Alexandrian scholars because of the passing mention of a former Pythian victory won by Hieron's horse Pherenikos' (Race 1997:2.242) and composed between 476 and 467 (Race 1997:252 n. 1). Robbins argues that Pherenikos' victory is included as a consolation to Hieron both for his disappointment at losing with Pherenikos in 474 and for his illness and defeat, and as a message of hope for the future (1990:312-313).

3 For the texts of Pindar and Bacchylides I have used the editions of Snell-Maehler 1987 and 1970 respectively. All translations are my own.

4 Schol. Pind. P. 3 Drachmann 2.62, ad Inscr. a; cf. the schol Pind. P. 1 (Drachmann 2.5), which mentions two Pythian victories, in 482 and 478. 
plural $\sigma \tau \varepsilon \varphi \alpha ́ v o เ \varsigma$ (line 72) referred to 'a plurality of victories', and that Hieron had

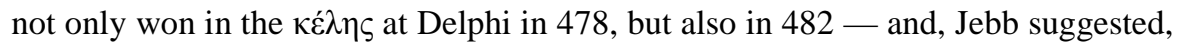
Hieron did so on both occasions with Pherenikos. ${ }^{5}$ Maehler points out that

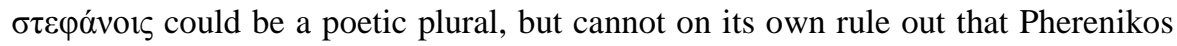
won more than once at Delphi. ${ }^{6}$ Robbins regards it as unlikely that the horse involved in both 482 and 476 was Pherenikos. He suggests that the scholiast may have understood $\sigma \tau \varepsilon \varphi \alpha ́ v o r \varsigma$ as a normal plural referring to multiple victories rather than as a poetic plural referring to a single victory, but concedes that the scholiast on $P$. 1 mentions Pythian victories in 482 and 478; further, that in 482 Hieron still ruled only Gela and, on succeeding his brother Gelon in 478, he became tyrant of Syracuse too (as mentioned in P. 3.70), a more appropriate time for Pherenikos' appearance. ${ }^{7}$ This argument makes sense and respects the surviving evidence, but is not conclusive. We shall return to the stallion's career anon. What is certain is the prominence given to the horse by the very act of naming him, which must surely indicate that the victory and the horse meant a great deal to Hieron. The equestrian races ( $\tau \dot{\varepsilon} \theta \rho \imath \pi \pi \mathrm{ov}$ and $\kappa \dot{\varepsilon} \lambda \eta \varsigma)$ were in themselves popular and prestigious events, already then 'the sport of kings', who could afford to breed horses purely for sport. ${ }^{8}$

After his next victory, at Olympia in $476,{ }^{9}$ the horse gets far more attention: both Pindar and Bacchylides devote lines to him. Pindar brings him up early in his First Olympian Ode, celebrating the victory of Hieron $(O .1 .17-22)$, 'perhaps his grandest production of all'. ${ }^{10}$

$\grave{\alpha} \lambda \lambda \grave{\alpha} \Delta \omega \rho i ́ \alpha v \dot{\alpha} \pi$ ò $\varphi o ́ \rho \mu 1 \gamma \gamma \alpha \pi \alpha \sigma \sigma \alpha ́ \lambda o v$

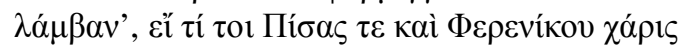

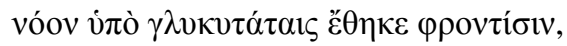

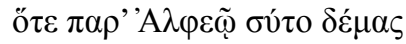

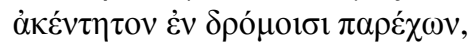

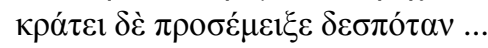

But from its peg take down

the Dorian lyre, if both Pisa's and Pherenikos' grace

Jebb 1967:274 ad loc.; 198 n. 2; so, too, Miller 1978:131.

Maehler 1982:78 n. 4.

Robbins 1990:307-308, 312 n. 25.

Thus Golden 2008:6-7.

9 The date is confirmed by $P$. Oxy. 222; Race 1997:44. There is no reason for Gildersleeve 1965:131 to state that the Pherenikos of Pyth. 3 'was doubtless grandsire' to the Pherenikos in $\mathrm{Ol}$. 1; see further below.

10 Hornblower 2004:16. 
has subjected your mind to sweetest thoughts, when beside the Alpheos he sped, giving his body ungoaded in the race, and brought his master to the pinnacle ...

This time the horse's qualities are enumerated: his physical grace, his ability to instil the most pleasant memories, first in the poet, and then no doubt in others, his natural power and speed without need of a goad and his superior strength which ensured victory for his owner. The terms used to describe the horse and his effect

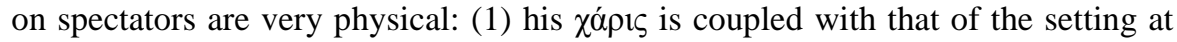

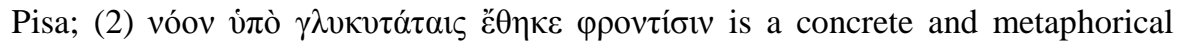
way of speaking about the psychological effect of the horse's performance; ${ }^{11}$

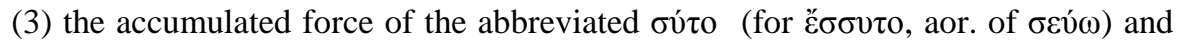

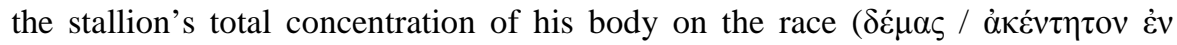

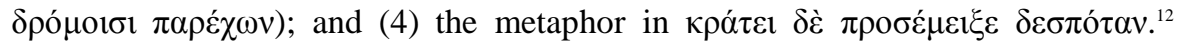
In this way the horse gains a strong presence in the audience's mind.

Additional prominence is given to the horse by its relation to the Pelops myth which dominates the ode. Köhnken has shown how close this connection is: in his quest for the hand of Hippodameia, Pelops is assisted in the chariot-race against Oinomaos, by Poseidon, patron god of horsemanship; крá $\tau \varepsilon 1$ is used for the 'power' bestowed on Hieron by Pherenikos' victory and the 'power' Pelops prays for if Poseidon grants victory to his team $(22,78)$; and whereas Hieron's victory in

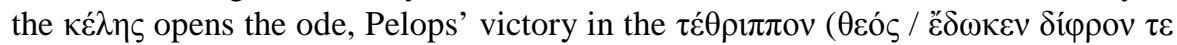

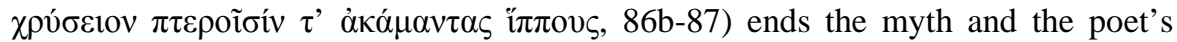

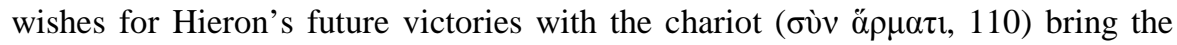
ode to a close. ${ }^{13}$

Bacchylides devotes two passages to Pherenikos in his Ode 5 (37-49, 176186). ${ }^{14}$ The first of these is placed at the end of the first epode (31-40) and the beginning of the second strophe (41-80), in the grand company of Hieron's

11 Compare the translations of Miller 1996:126 ("placed your mind beneath the spell of sweetest thoughts') and of Race 1997:49 ("enthralled your mind with sweetest considerations').

12 LSJ s.v. $\pi \rho \circ \sigma \mu \varepsilon i ́ \gamma v 0 \mu$. Miller's version (1996:126: 'infused his lord with mastery') is bold, but probably the wrong metaphor; Race's (1997:49: 'joined to victorious power') is closer to the Greek. Bowra's view 1964:166, that 'such admiration as he (Pindar) has for Pherenicus is more moral than physical, for his character more than for his beauty as revealed in action', does not give due significance to Pindar's description.

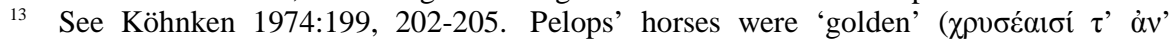

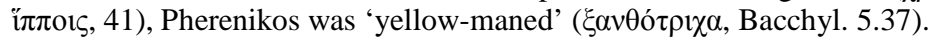

14 For the identification see Smyth 1963:398-399; Gentili 1958:13-14. 
excellence, military successes and father Deinomenes, and of Nike, Ares and the river Alpheos.

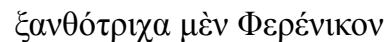

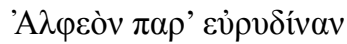

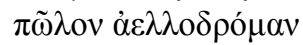

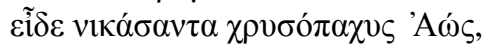

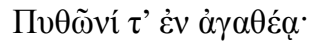

$\gamma \tilde{\alpha} \delta^{\prime} \dot{\varepsilon} \pi \imath \kappa \kappa \eta \dot{\pi} \tau \omega \nu \pi \iota \varphi \alpha v ́ \sigma \kappa \omega$.

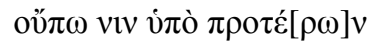

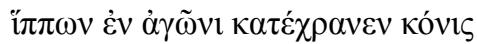

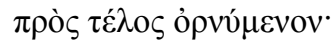

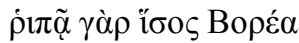

ôv $\kappa \nu \beta \varepsilon \rho v \eta ́ \tau \alpha v ~ \varphi v \lambda \alpha ́ \sigma \sigma \omega v$

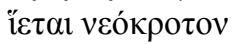

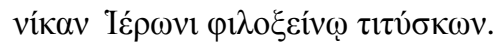

And chestnut-maned Pherenikos, along the wide-eddying Alpheos, a colt as swift as a storm,

was seen winning by golden-armed Dawn,

and in divine Pytho too;

and I touch the earth and proclaim:

never yet has the dust from leading

horses in a contest dirtied him

as he sprinted to the finish;

for with a rush like the North Wind, and looking after his steersman

he speeds, preparing

a newly-applauded victory for hospitable Hieron.

The position of the description is significant, starting as it does in the epode of the first triad. Here we must bear in mind the effect in the live performance of the ode. For the strophe the chorus moved to their right, in the antistrophe to their left, maintaining in both the same rhythm and dance-movements. For the epode the 
chorus came to a stop in the centre, facing the audience before delivering the words. $^{15}$

The particular qualities thus brought to the audience's attention are his distinctive chestnut mane, his previous victory at Olympia, his speed there (like a storm), the occasion in the early morning enhanced by reference to the mythological Dawn, his latest victory at Olympia, where he didn't even pick up dust from the other horses, his speed like the North wind, his obedience to his jockey and presentation of a new accolade for Hieron. A closer examination of the words reveals a very poetical and unusual depiction. Although $\pi \tilde{\omega} \lambda \mathrm{o} \varsigma$ is strictly a young horse or colt, and is used by poets for i $\pi \pi$ o (LSJ), we should admit the possibility that this is a young Pherenikos at the start of his career, say, three years old. ${ }^{16}$ The epithet used with $\pi \tilde{\omega} \lambda \circ \varsigma$, namely $\dot{\alpha} \varepsilon \lambda \lambda o \delta \rho o ́ \mu \alpha v$ ('storm-swift') is a hapax

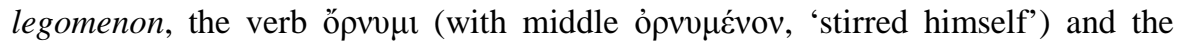
noun $\dot{\rho} \iota \pi \tilde{\alpha}$ are found only in poetry (the latter echoing Homer, Il. 15.171 and

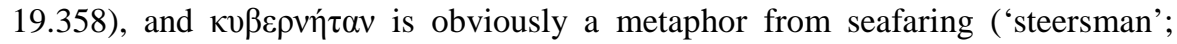
'guide', 'rider'). In the case of $\varphi v \lambda \alpha ́ \sigma \sigma \omega v$, two meanings are possible: 'protecting', 'preserving' (cf. Bowra 1964: 'he looks after his pilot'; Miller 1996:206: 'keeping the man who steers him safe') or 'observing' (cf. Campbell 1992:141: 'heeding his steersman'). If Pherenikos made a habit of winning his races without the need of his rider's goad, as Pindar mentioned ( $O .1 .21$, above), then the second meaning seems less probable, while the first gains extra significance: by its natural pace the horse saves the jockey from harm and unnecessary effort. Finally, the adjective

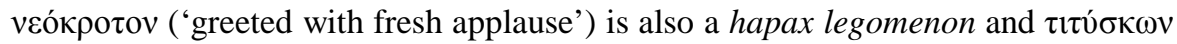
occurs in epic, and rarely.

The second passage on Pherenikos occurs towards the end of the poem, in the antistrophe of the fifth triad (176-186):

15 Schol. Pind. 3.306.16-307.5 Drachmann: 'One must know that the lyric poets, in their poems, used strophe, antistrophe and epode. "Strophe", because the singers turned from the right to the left ... "Antistrophe", because the singers moved from the left to the right ... "Epode", because they came to a standstill in the one place and performed the odes'; Schol. Pind. 3.307.7-20 Drachmann: 'Because Pindar is a lyric poet, and sang his poems to the accompaniment of the lyre, his songs are constructed in triads of strophe, antistrophe and epode, and of cola. Whatever the size and nature of the strophe, the antistrophe was the same, but the epode was different from them, and suitably so, since the strophe was preferred by the dancers as they moved to the right, the antistrophe as they moved from the right to the left, but the epode was performed as they stood still'.

16 Thus Jebb 1967:198 n.2. If this is correct, it means that, since races specifically for colts only date from 384, Pherenikos was racing against older, more experienced horses. 


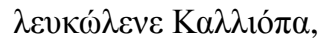

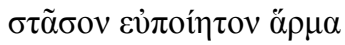

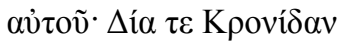

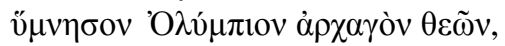

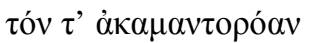

'A $\lambda \varphi \varepsilon o ́ v, ~ \Pi \varepsilon ́ \lambda o \pi o ́ \varsigma \tau \varepsilon \beta i ́ \alpha v$,

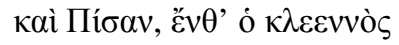

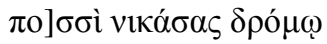

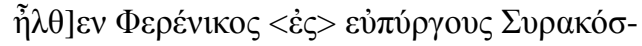

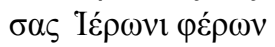

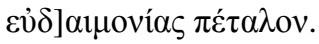

White-armed Kalliope,

halt your well-made chariot here: sing of Zeus, son of Kronos,

Olympian, ruler of the gods, and of the unwearied stream,

Alpheos, and of Pelops' power, and of Pisa, where the famous

Pherenikos with his hooves won in the race and came to well-towered Syracuse, bringing to Hieron the leaf of good fortune.

The position is again significant: the poet's summoning of the Muse Kalliope for her help in the last antistrophe signals the beginning of the build-up to the climax of the ode. The horse again appears in company with deities (Kalliope and Zeus) and the human victor (Hieron) and in a passage of highly poetic language:

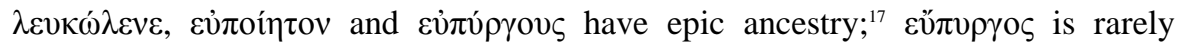

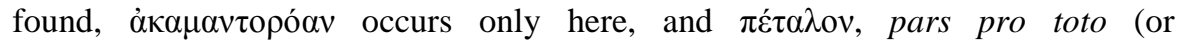
synecdoche) for the victor's olive wreath, is uncommon in the singular and used only here of the wild olive. ${ }^{18}$

We can see that the two poets in their descriptions select different details for emphasis: Pindar conveys the horse's graceful appearance, unforgettable effect on spectators, unstimulated speed and concentrated power, and ability to bring victory and renown to its owner; Bacchylides highlights his appearance, previous

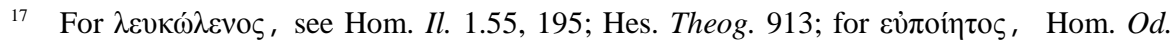

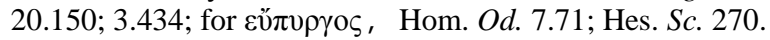


achievement at Olympia, his speed which leaves other horses behind, his obedience and the new applause his victory has brought Hieron. Bowra is right in noting that Bacchylides 'enters thoroughly into the excitement of the race', but not in concluding that such interest in the actual course is absent in Pindar's description. ${ }^{19}$ Lefkowitz draws a more valid comparison when she observes that in Pindar the horse is the 'center of attention', while Bacchylides focuses on the 'extraordinary circumstances of the victory'. ${ }^{20}$ Bernardini shares this view, emphasising that Pindar attributes the horse's success to its ability and trainer, and not to fortune, while Bacchylides' description is more detailed, richer in colour and pathos, abounding in adjectives, with a linear syntactical structure and simile that give the event an epic colouring and situate it in an extratemporal dimension. ${ }^{21}$ Each poet thus has an individual view and creative mind, and, rather than comparing them (usually to the detriment of Bacchylides), we need to gain clearer understanding of the potential meanings of the individual texts.

At this stage one can reconstruct the rest of the racing-career of Pherenikos begun above for 482 and 478 (on Pind. P. 3). A papyrus fragment of the Olympic register (P.Oxy. 2.222, col. 1.19 and 32; Miller 2004a:91, no. 129) and the scholiast on Pind. O. 1 (Drachmann 1.15-16, inscr. a) record that Hieron won at Olympia in 476 (Ol. 76; Pind. O. 1; Ba. 5) and 472 (Ol. 77). ${ }^{22}$ According to Paus. 8.42.8-9, Hieron won successive victories in two-year intervals, and his son, Deinomenes, dedicated an inscription to his father, naming his Olympic victories,

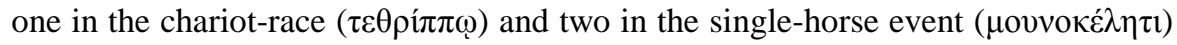
— in 476 and 472 . No horse is named, and there is no evidence that Pherenikos was the winner in $472 .{ }^{23}$ Robbins reconstructed Hieron's racing-results as follows: won in 482 at Delphi (but probably not with Pherenikos), in 478 at Delphi (with Pherenikos), in 476 at Olympia (with Pherenikos at his peak), ${ }^{24}$ in 472 at Olympia (but probably with another horse). Into this scheme Robbins inserts a loss with Pherenikos in 474 at Delphi. ${ }^{25}$ If this scheme is correct, it would give this great horse a triumphant run of two years $(478-476)$. If the horse was five years old when he won in 478 , he would have been seven in 476 . If one also supposes that Pherenikos won in 482 , as the scholiast states, his career, including possible defeat

19 Bowra 1964:165.

20 Lefkowitz 1984:36, 39.

21 Bernardini 1985:127.

22 Jebb 1967:198-199; Maehler 1982:78.

23 Maehler 1982:78, 80.

24 Maehler 1982:79 n. 6 remarks that Bacchylides' description in lines 43-49 is more applicable to an eight-year-old than a twelve-year-old horse.

25 Robbins 1990:312-313. There is also complete silence about the Olympics in 480, which raises unanswerable questions as to whether Pherenikos lost or even participated. 
in 474, would have spanned eight years and made him about thirteen years old. ${ }^{26}$ This is speculative, but not impossible for a race-horse in ancient or modern times. $^{27}$

Bacchylides returns to praise Pherenikos in Fr. 20C, lines 2-11, this time from an enkomion:

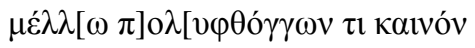

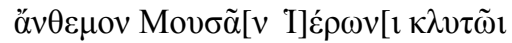 \\ $\xi \alpha v \theta \alpha \tilde{\sigma} \sigma \mathrm{i} \pi \pi \mathrm{ol \varsigma}$

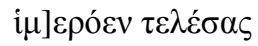

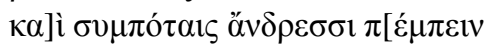

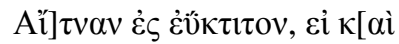

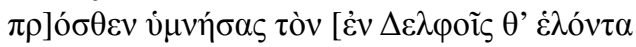

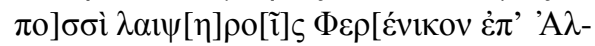 \\ $\varphi[\varepsilon 1] \tilde{\omega} \iota \tau \varepsilon v[i] \kappa \alpha \nu$ \\ $\dot{\alpha} v[\delta] \rho[\grave{\imath} \chi] \alpha \rho \jmath \zeta o ́ \mu \varepsilon v o \varsigma$
}

2, 8, 9 suppl. Snell 3 suppl. Maas

I intend, having completed something

fresh, a lovely flower of the Muses [of many notes],

[to send] to Hieron, [renowned]

for his chestnut-coloured mares

26 Cf. Jebb 1967:198 n. 2. Miller 1978:131-132 adds possible victory in 472, extending the horse's career to ten years.

27 Hdt. 6.103 records that Miltiades' father, Kimon, won the four-horse chariot race at Olympia three times $(532,528,524)$ with the same team of mares, a feat equalled by Evagoras. In the $4^{\text {th }}$ century $\mathrm{AD}$, Pelagonius (De arte veterin. 32) notes that horses aged five to twenty were usually suitable for the circus and contests (equos circo sacrisque certaminibus quinquennes usque ad annum XX plerumque idoneos adseverant). Cf. Jebb 1967:198 n. 2, who refers to the case of a Grand National multiple winner: The Lamb (1868, 1871 at six and nine years old respectively); and a report in The Times of March 26, 1904 that, of the twenty-six horses starting, four were nine years old, one was ten, another thirteen, another sixteen. Also Maehler 1982:79 n. 6, who mentions an English horse called The Brigadier, which over a period of three years ran eighteen races, won seventeen and came second in the remaining one. The breakdown for Grand National winners from 1950-2011 is: twelve-year-olds nine; elevenyear-olds eight; ten-year-olds thirteen; nine-year-olds twenty-one; and eight-year-olds ten (http://www.grandnational.org.uk). Miller 1978:152 n. 18 reminds us that the ancient $\kappa \varepsilon ́ \lambda \eta \varsigma$ differed considerably from a modern-day flat race; the shape of the ancient Greek hippodrome, with its sharp turns at either end, required horses with skill, experience and speed. 
and the men who share his banquets

in well-built Aitna, if [also] previously

I sang of Phere[nikos who won

both at Delphi] with his swift feet [and at the Al-]

pheos a victory,

bringing delight to the man ...

Since this fragment of an enkomion was recovered from a first century papyrus (POxy 1361 frr. 4 al.), there is no external information on the context or occasion apart from what can be gleaned from the surviving text. Hieron is praised again for his chestnut horses, with $\xi \alpha v \theta \alpha i \sigma v v i \pi \pi$ ors (4) recalling the colour of Pherenikos' mane in Ode 5.37 ( $\xi \alpha v \theta$ ó $\rho \imath \chi \alpha)$ and thereby connecting the racehorse with the

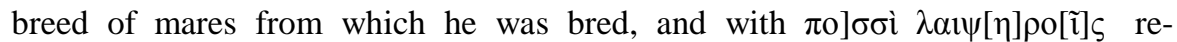
emphasising the speed of this famous horse. Also selected for praise are Hieron's fellow-symposiasts $(\sigma \nu \mu \pi$ ó $\tau \alpha 1 \varsigma ~ \alpha ̈ v \delta \rho \varepsilon \sigma \sigma 1,6)$ in whose presence, presumably, the ode will be performed. Then Bacchylides refers to two previous victories, at Delphi and Olympia, for which he composed odes (6-16). These victories are almost certainly those in 478 and 476 . The rest of the fragmented ode yields further details: Hieron's (?) lack of cowardice among mortals (17-18), Hieron's (?)

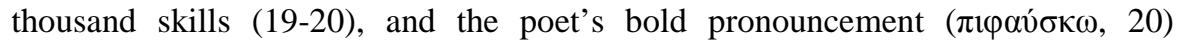

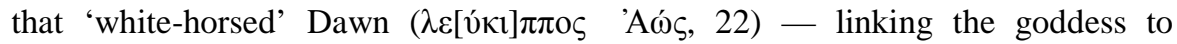
horse-racing - shines on no greater mortal of the same age (21-24). This last phrase ( $\dot{\varepsilon} \varphi$ ' $\left.\dot{\alpha} \lambda \kappa_{\kappa}^{\prime} \alpha[1], 23\right)$ suggests an older Hieron, to whom the poet has addressed the encomium.

\section{BIBLIOGRAPHY}

Bernardini, P A 1985. 'L'attualità agonistica negli epinici di Pindaro.' In André Hurst (ed.), Pindare. Huite exposés suivis de discussions. Entretiens sur l'Antiquité Classique, Tome XXXI, 117-153. Vandoeuvres-Genève: Fondation Hardt.

Bowra, C M 1964. Pindar. Oxford: Clarendon Press.

Campbell, D A 1992. Greek lyric IV: Bacchylides, Corinna, and others. LCL 461. Cambridge, Mass. \& London: Harvard University Press.

Drachmann, A B 1964. Scholia Vetera in Pindari Carmina. 3 vols. Leipzig: Teubner Verlag (1903).

Gentili, B 1958. Bacchilide: Studi. Urbino: Università di Urbino.

Gildersleeve, B L 1965. Pindar. The Olympian and Pythian odes. Amsterdam: Hakkert (New York 1890).

Golden, M 2008. Greek sport and social status. Austin: Texas University Press. 
Hemingway, S A 2004. The horse and jockey from Artemesion: A bronze equestrian monument of the Hellenistic period. Berlin, Los Angeles \& London: University of California Press.

Hornblower, S 2004. Thucydides and Pindar. Historical narrative and the world of Epinikian poetry. Oxford: University Press.

Jebb, R C 1967. Bacchylides. The poems and fragments. Hildesheim: Georg Olms (Cambridge 1905).

Köhnken, A 1974. Pindar as innovator: Poseidon Hippios and the relevance of the Pelops story in Olympian 1. CQ 24:199-206.

Lefkowitz, M R 1984. The poet as athlete. Journal of Sport History 11.2:18-24.

Maehler, H 1982. Die Lieder des Bakchylides. Erster Teil: Die Siegeslieder. II. Kommentar. Leiden: E.J. Brill.

Miller, A 1996. Greek lyric. An anthology in translation. Indianapolis \& Cambridge: Hackett Publishing Company, Inc.

Miller, S G 1978. The date of the first Pythiad. CSCA 11:127-158.

Miller, S G 2004. Arete. Greek sports from ancient sources. 3rd and expanded ed. Berkeley, Los Angeles \& London: University of California Press.

Race, W H 1997. Pindar. Vol. 1: Olympian odes, Pythian odes. LCL 56; Vol. 2: Nemean odes, Isthmian odes, fragments. LCL 485. Cambridge, Mass. \& London: Harvard University Press.

Robbins, E 1990. The gifts of the gods: Pindar's third Pythian. CQ 40:307-318.

Smyth, H W 1963. Greek Melic poets. New York: Biblo \& Tannen (1899).

Snell, B \& Maehler, H 1970. Bacchylidis carmina cum fragmentis. Leipzig: Teubner Verlagsgesellschaft.

Snell, B \& Maehler, H 1987. 8th edition. Pindar. Pars I: Epinicia. Leipzig: Teubner Verlagsgesellschaft. 